\title{
Comparative Study of Pituitary-Thyroid Hormone Economy in Fasting and Hypothyroid Rats
}

Donald L. St. Germain and Valerie Anne Galton

Departments of Medicine and Physiology, Dartmouth Medical School, Hanover, New Hampshire 03756

\section{Abstract}

Starvation in laboratory rodents results in significant alterations in thyroid hormone economy characterized by decreased circulating levels of thyroxine $\left(T_{4}\right)$ and $3,5,3$-triiodothyronine $\left(\mathrm{T}_{3}\right)$ and a decline in serum thyrotropin (TSH) concentration. To investigate this apparent paradox, we have compared in fasted and hypothyroid animals the intracellular parameters mediating thyroid hormone action in the anterior pituitary gland. In vitro saturation analysis combined with quantitation of nuclear $T_{3}$ content by radioimmunoassay allowed for characterization of pituitary nuclear $T_{3}$ receptors and estimation of the endogenous fractional receptor occupancy. In rats, thyroidectomized 4 wk earlier, the 10-fold increase in serum TSH levels and decline in peripheral thyroid hormone concentrations were accompanied by a $61 \%$ decrease in pituitary nuclear $T_{3}$ content and a marked decline in fractional $T_{3}$ receptor occupancy as compared with control animals. In euthyroid animals subjected to short-term starvation ( $72 \mathrm{~h}$ ), serum $\mathrm{T}_{3}, \mathrm{~T}_{4}$, and TSH levels declined by 52, 43, and $48 \%$, respectively. Despite these marked decreases in circulating thyroid hormone levels, pituitary nuclear $T_{3}$ content in fasted rats declined by only $15 \%$ $(P<0.05)$ relative to control levels. This modest decline in nuclear $\mathbf{T}_{3}$ content, combined with a $23 \%$ decrease in total $\mathbf{T}_{3}$ receptor number, resulted in an estimated fractional receptor occupancy in fasted animals which was equal to or greater than that noted in controls. The effects of fasting and hypothyroidism on the pituitary were further investigated by quantifying low Michaelis constant $\left(\dot{K}_{\mathrm{m}}\right) T_{4} 5^{\prime}$-deiodinase activity in the crude cytosol fraction of pituitary homogenates. In thyroidectomized animals, maximum velocity was increased ninefold, whereas fasting resulted in a $37 \%$ decrease $(P<0.025)$ in this parameter compared with controls. $K_{m}$ values were similar in all experimental groups $(4.7 \pm 0.6 \mathrm{nM})$.

These results demonstrate that, despite significant reductions in circulating thyroid hormone concentrations and pituitary $T_{4}$ 5'-deiodinase activity, nuclear $T_{3}$ levels are maintained at relatively normal levels in the pituitary of the fasted animal and fractional $T_{3}$ receptor occupancy may actually increase. These findings are in marked contrast to those noted in thyroidectomized animals and suggest that the suppression of TSH secretion accompanying starvation in the rat is mediated, at least in part, by local pituitary mechanisms that serve to maintain and possibly enhance nuclear $T_{3}$ receptor occupancy.

Portions of these studies were presented at the 65th annual meeting of the Endocrine Society, June 1983, at San Antonio, Texas.

Received for publication 19 October 1983 and in revised form 25 October 1984.

J. Clin. Invest.

(c) The American Society for Clinical Investigation, Inc.

$0021-9738 / 85 / 02 / 0679 / 10 \quad \$ 1.00$

Volume 75, February 1985, 679-688

\section{Introduction}

In both humans and laboratory animals, nutritional status profoundly affects thyroid hormone economy and pituitary function (1-4). In humans, short-term starvation is accompanied by significant decreases in, serum total and free 3,5,3'-triiodothyronine $\left(T_{3}\right)^{1}$ levels whereas thyroxine $\left(\mathrm{T}_{4}\right)$ levels are unaltered or slightly elevated $(1,3,5,6)$. In rodents, a 48 72-h fast results in marked depressions of both free and total $T_{3}$ and $T_{4}$ serum levels $(7,8)$. Evidence now suggests that these lowered peripheral thyroid hormone levels have a proteinsparing effect and thus may be of considerable adaptive value $(6,9-12)$.

The hypothalamic-pituitary axis appears to play an important role in maintaining the apparent thyroid hormonedeficient status of fasting animals. Thus, despite decreased peripheral thyroid hormone levels, serum thyrotropin (TSH) levels do not rise $(1,3,5,6)$. Indeed, in the rat, inanition results in decreased serum and intrapituitary TSH levels and eventual thyroid gland atrophy $(2,7,13)$. The pituitary, however, remains sensitive to thyroid hormone feedback (6, $14,15)$ and the diurnal rhythm of TSH secretion is unchanged (16) suggesting an altered "set-point" for TSH regulation in the starving animal.

The physiologic mechanisms responsible for these adaptive changes in pituitary function are uncertain, but they could result from alterations in the secretion of hypothalamic hormones or be mediated by direct effects of nutritional deptivation as noted in the liver (17). Alternatively, fasting could induce changes in thyroid hormone economy in the pituitary. Only limited data are available, however, concerning the effects of starvation on the pituitary cellular mechanisms that influence thyroid hormone action. Based on the results of a single experiment using in vivo saturation techniques, Bavli (18) has suggested that pituitary nuclear $T_{3}$ receptor levels are decreased in fasting rats. Others have reported that pituitary $T_{4} 5^{\prime}$ deiodinase activity is unchanged $(19,20)$ or decreased $(21,22)$ with starvation. How these alterations relate to fasting-induced changes in pituitary function is uncertain.

In the present study, we have utilized in vitro techniques to examine and compare in the rat the effects of short-term starvation and hypothyroidism on pituitary nuclear $T_{3}$ receptor levels, nuclear $T_{3}$ content, and the kinetics of $T_{4} 5^{\prime}$-deiodination. Our results demonstrate marked differences in pituitary-thyroid hormone economy in these two conditions. These differences may have important implications in the control of pituitary function and TSH secretion.

1. Abbreviations used in this paper: DTT, dithiothreitol; MBC, maximum binding capacity; NSB, nonspecific binding; $T_{3}, 3,5,3^{\prime}$-triiodothyronine; $\mathrm{T}_{4}$, thyroxine; TSH, thyrotropin. 


\section{Methods}

Male Sprague-Dawley rats were obtained from Charles River Breeding Laboratories, Inc. (Wilmington, MA) and were kept under conditions of controlled lighting and temperature. Fasting experiments (protocol I) were conducted with 8-wk-old animals that had initial weights of 200-225 g. Before killing, animals were fasted for a 72-h period during which time they were allowed free access to water and housed individually in metal cages with wire-mesh floors to prevent coprophagia. Control animals were maintained in a similar manner but were allowed free access to pelleted rat diet. For experiments involving hypothyroid and $T_{4}$-injected animals (protocol II), normal and thyroidectomized rats ( 7 wk old, $175-200 \mathrm{~g}$ in initial body wt) were purchased from the same supplier. Animals were housed in pairs in clear plastic cages with wood shavings for bedding and were given free access to food and water. Thyroidectomized animals were given drinking water containing calcium lactate $(0.9 \mathrm{~g} / \mathrm{dl})$. Animals were killed 4-5 wk postsurgery. $\mathrm{T}_{4}$-treated animals received $30 \mu \mathrm{g}$ of $\mathrm{T}_{4} / 100 \mathrm{~g}$ of body wt injected subcutaneously for $18 \mathrm{~d}$ before killing and were utilized $24 \mathrm{~h}$ after the last injection.

Tissue preparation. Animals were stunned and decapitated, and trunk blood was collected. Anterior pituitaries from 4 to 11 animals in each experimental group were pooled, weighed, and homogenized by hand in $30 \mathrm{vol}(\mathrm{wt} / \mathrm{vol})$ of ice-cold homogenate buffer $(0.25 \mathrm{M}$ sucrose, $0.02 \mathrm{M}$ Tris- $\mathrm{HCl}, \mathrm{pH} 7.6,1 \mathrm{mM} \mathrm{MgCl} 2,2 \mathrm{mM} \mathrm{CaCl}, 0.1$ $\mathrm{mM}$ dithiothreitol [DTT], 5\% glycerol). Subsequent procedures were carried out at $0-4^{\circ} \mathrm{C}$. The crude homogenate was centrifuged at $800 \mathrm{~g}$ for $10 \mathrm{~min}$, and the supernate (designated cytosol hereafter for convenience) was used immediately for determination of $T_{4} 5^{\prime}$-deiodinase activity as described below. The pellet was utilized to prepare a purified suspension of isolated nuclei (verified by Nomarski interferencecontrast techniques) by modification of the method of Spindler et al. (23). The pellet was washed twice with $2.5 \mathrm{ml}$ of homogenate buffer containing $0.5 \%$ Triton $\mathrm{X}-100$, and then washed once and resuspended in incubation buffer $(0.25 \mathrm{M}$ sucrose, $0.02 \mathrm{M}$ Tris- $\mathrm{HCl}, \mathrm{pH} 7.6,1 \mathrm{mM}$ $\mathrm{MgCl}_{2}, 0.1 \mathrm{mM}$ DTT, $2 \mathrm{mM}$ EDTA, $50 \mathrm{mM} \mathrm{NaCl}, 5 \%$ glycerol) using a Dounce glass homogenizer. Aliquots of the nuclear suspension were then utilized in $\mathrm{T}_{3}$ saturation studies. $\sim 60 \%$ of the DNA in the crude homogenate (as determined by the method of Burton [24]) was recovered in the purified nuclear preparation.

Characterization of nuclear $T_{3}$ binding sites. Aliquots of the nuclear suspension containing 15-35 $\mu \mathrm{g}$ DNA were incubated in a total volume of $1 \mathrm{ml}$ of incubation buffer containing $4 \times 10^{-11} \mathrm{M}^{125} \mathrm{I}_{-} \mathrm{T}_{3}$ (sp act $\sim 1,200 \mu \mathrm{Ci} / \mu \mathrm{g}$, New England Nuclear, Boston, MA) and stable $\mathrm{T}_{3}$ (Siğma Chemical Co., St. Louis, MO) sufficient to yield total concentrations of $5 \times 10^{-11}$ to $5 \times 10^{-9} \mathrm{M}$. Nonspecific binding (NSB) of ${ }^{125} \mathrm{I}_{-} \mathrm{T}_{3}$ was determined in all experiments by incubating nuclei with 1 or $5 \times 10^{-7} \mathrm{M}$ stable $\mathrm{T}_{3}$. Incubations were performed at $22^{\circ} \mathrm{C}$ or $37^{\circ} \mathrm{C}$ for varying periods of time. After incubation, nuclei were chilled to 0 $4^{\circ} \mathrm{C}$ and centrifuged at $1,200 \mathrm{~g}$ for $10 \mathrm{~min}$, and a $0.5-\mathrm{ml}$ aliquot of supernate removed for determination of free hormone concentration by absorption on dextran-coated charcoal (25). Greater than $94 \%$ of the total hormone in the supernate was in the free form. The nuclear pellet was washed once with an ice-cold solution of $0.5 \%$ Triton X100 (in $0.25 \mathrm{M}$ sucrose, $0.02 \mathrm{M}$ Tris- $\mathrm{HCl}, \mathrm{pH} 7.6,1 \mathrm{mM} \mathrm{MgCl}_{2}, 0.1$ mM DTT, $5 \%$ glycerol), resuspended in $0.5 \mathrm{ml}$ of homogenate buffer, and counted in an automatic gamma counter (model 1195, Amersham/ Searle, Arlington Heights, IL). The suspension was then stored at $-20^{\circ} \mathrm{C}$ for subsequent DNA analysis. The single Triton X-100 wash reduced NSB of ${ }^{125} \mathrm{I}-\mathrm{T}_{3}$ to $<6 \%$ of total binding. Scatchard analysis (26) of the binding data was carried out graphically (27). Points represent single determinations.

Several experiments (each performed at least twice) were undertaken to determine the optimal conditions for saturation analysis. (a) The time course of in vitro association of $T_{3}$ to isolated pituitary nuclei was determined by incubating aliquots of nuclei from euthyroid animals with $10^{-10} \mathrm{M}^{125} \mathrm{I}_{-} \mathrm{T}_{3}$ for varying lengths of time and then quantitating the amount of bound ${ }^{125} \mathrm{I}_{-} \mathrm{T}_{3}$. (b) The rate of dissociation after in vitro labeling was measured by adding $5 \times 10^{-1} \mathrm{M}$ stable $\mathrm{T}_{3}$ to aliquots of nuclei previously incubated with $10^{-10} \mathrm{M}^{125} \mathrm{I}_{-} \mathrm{T}_{3}$ and determining the time course of disappearance of radioactivity from the nuclear pellet. (c) To determine the rate of in vitro dissociation of endogenously bound $T_{3}$, euthyroid rats were injected intravenously with a "tracer" amount of ${ }^{125} \mathrm{I}-\mathrm{T}_{3}(4 \mathrm{ng} / 100 \mathrm{~g}$ body wt in phosphatebuffered saline containing $10 \%$ normal rat serum) 60 min before killing. Pituitary nuclei were then isolated and incubated with $10^{-6} \mathrm{M}$ stable $T_{3}$. At varying time intervals the nuclei were chilled to $0-4^{\circ} \mathrm{C}$, and bound ${ }^{125} \mathrm{I}-\mathrm{T}_{3}$ was determined as described above. The rate of dissociation was estimated by determining the time course of both ${ }^{125} \mathrm{I}$ $T_{3}$ disappearance from the nuclear pellet and ${ }^{125} I-T_{3}$ appearance in the incubation medium. NSB was assessed in a second group of euthyroid rats by the simultaneous injection of $20 \mu \mathrm{g}$ of stable $\mathrm{T}_{3} / 100 \mathrm{~g}$ of body wt with the ${ }^{125} \mathrm{I}-\mathrm{T}_{3}$. NSB was $3 \%$ of total ${ }^{125} \mathrm{I}-\mathrm{T}_{3}$ binding. $(d)$ To assess further the effects of incubation conditions on the saturation analyses, euthyroid rats were injected intravenously with sufficient stable $T_{3}$ to saturate the nuclear receptor sites completely $\left(25 \mu \mathrm{g}\right.$ of $\mathrm{T}_{3} / 100 \mathrm{~g}$ of body wt). Animals were killed 90 min later, pituitary nuclei were prepared, and saturation studies were performed under various conditions of time and temperature. Euthyroid animals injected with an equivalent volume of vehicle served as controls.

Determination of nuclear $T_{3}$ content. The amount of $T_{3}$ present in pituitary nuclei was determined by radioimmunoassay (RIA) according to the methods of Larsen et al. (28). Individual rat anterior pituitary glands were homogenized by hand in $1 \mathrm{ml}$ of homogenate buffer. Isolated pituitary nuclei were prepared as described above and extracted twice with $0.5 \mathrm{ml}$ of absolute ethanol at $37^{\circ} \mathrm{C}$ for $30 \mathrm{~min}$. The nuclear pellet was then stored at $-20^{\circ} \mathrm{C}$ for subsequent DNA analysis. The two extracts for a given sample were pooled and stored at $-20^{\circ} \mathrm{C}$ for subsequent $\mathrm{T}_{3}$ RIA. Extraction efficiency was determined by injecting euthyroid rats intravenously with "tracer" amounts of ${ }^{125} \mathrm{I}_{-} \mathrm{T}_{3}(4 \mathrm{ng} /$ $100 \mathrm{~g}$ body wt) $60 \mathrm{~min}$ before killing. Recovery of ${ }^{125} \mathrm{I}_{-} \mathrm{T}_{3}$ in the nuclear extract was $84.3 \pm 1.8 \%$ in the first ethanol extract and $96.7 \pm 2.5 \%$ after two extractions. NSB of ${ }^{125} \mathrm{I}_{-} \mathrm{T}_{3}$ was $3 \%$ as noted earlier, thus no correction for extraction efficiency or NSB was applied.

Determination of $T_{4} 5^{\prime}$-deiodinase activity. $\mathrm{T}_{4} 5^{\prime}$-deiodinase activity was determined in the cytosol fraction of the crude pituitary homogenate by modification of the methods of Kaplan (21). $T_{4}$ was obtained from Henning, Co. (Berlin, Federal Republic of Germany) and contained $<0.1 \% \mathrm{~T}_{3}$ by the manufacturer's specifications. Aliquots $(190 \mu \mathrm{l})$ of cytosol enriched with DTT to a final concentration of $20 \mathrm{mM}$ were preincubated at $37^{\circ} \mathrm{C}$ for $10 \mathrm{~min}$ in stoppered plastic vessels. $T_{4}$ was then added as a $10-\mu \mathrm{l}$ aliquot in $0.25 \mathrm{M}$ sucrose, $0.05 \mathrm{M}$ Tris- $\mathrm{HCl}$, $\mathrm{pH}$ 7.6 , to yield a final concentration of $1.4-100 \mathrm{nM}$. Duplicate $40-\mu \mathrm{l}$ samples of reaction mixture were then immediately removed for zero time samples and each mixed with $80 \mu \mathrm{l}$ of ice-cold $95 \%$ ethanol. Incubation was then carried out for $10-30 \mathrm{~min}$ at $37^{\circ} \mathrm{C}$ after which duplicate samples were again obtained. After storage at $4^{\circ} \mathrm{C}$ for $24-36$ $\mathrm{h}$, ethanol extracts were centrifuged at $12,000 \mathrm{~g}$ and the supernate fraction stored at $-20^{\circ} \mathrm{C}$ until assayed for $T_{3}$ by RIA. Recovery of $T_{3}$ by ethanol extraction of the reaction mixture was $>96 \%$. Protein was determined on aliquots of cytosol before enrichment with DTT by the method of Lowry et al. (29). Kinetic data were analyzed by EadieHofstee plots (30).

RIA methods. $\mathrm{T}_{3}$ concentrations in ethanol extracts and serum were determined by RIA by modification of the procedures of Larsen et al. $(28,31)$. A 5-d, nonequilibrium assay method with a combined polyethylene-glycol/second antibody separation step was employed. For cytosolic ethanol extracts from $\mathrm{T}_{4} 5^{\prime}$-deiodinase experiments, the assay buffer consisted of $0.2 \mathrm{M}$ glycine, $0.13 \mathrm{M}$ sodium acetate, $\mathrm{pH}$ 8.6 , with $20 \mathrm{mg} / \mathrm{dl}$ bovine serum albumin. Extract aliquots $(10 \mu \mathrm{l})$ were assayed directly and equivalent volumes of ethanol/homogenate buffer were added to the standard curve. Specifically-bound ${ }^{125} \mathrm{I}-\mathrm{T}_{3}$ in the "zero" binding tubes ranged from 25 to $35 \%$. NSB in the standard tubes was $<2.0 \%$. In sample tubes NSB was $2-4 \%$ and was determined for representative samples in all assays. Assay sensitivity, defined as the dose of $T_{3}$ resulting in ${ }^{125} \mathrm{I}-\mathrm{T}_{3}$ displacement from antibody greater 
than three standard deviations from the zero binding, varied from 0.2 to $0.6 \mathrm{pg} /$ tube. The amount of $\mathrm{T}_{3}$ resulting in $50 \%$ displacement of tracer from zero binding was 3-6 pg/tube. Logit-log plots of the standard curve were linear from 0.2 to $30 \mathrm{pg} /$ tube. Intra- and interassay coefficients of variation were $6 \%$ and $9 \%$, respectively, at $3 \mathrm{pg}$ of $\mathrm{T}_{3} /$ tube.

Before assay, nuclear ethanol extracts were dryed under $\mathrm{N}_{2}$ at $37^{\circ} \mathrm{C}$ and then reconstituted in $100 \mu \mathrm{l}$ of $0.1 \mathrm{~N} \mathrm{NaOH}, 565 \mu$ l RIA assay buffer, and $35 \mu \mathrm{l}$ of human serum previously treated with an ion exchange resin (32). Recovery of $\mathrm{T}_{3}$ from the dried sample was $>99 \%$. Duplicate 200- $\mu \mathrm{l}$ aliquots of this mixture were then assayed for $T_{3}$ content with a third aliquot used to determine NSB. For these assays $10 \mu \mathrm{l}$ of resin-treated human serum was added to the standard curve and $2.74 \mathrm{~g} / \mathrm{dl}$ sodium salicylate was included in the assay buffer. Assay sensitivity was $0.4-1.0 \mathrm{pg}$ of $\mathrm{T}_{3} /$ tube with $50 \%$ displacement of tracer occurring with 6-10 pg of $T_{3} /$ tube. Dilutions of nuclear extracts over an eightfold range were parallel to the standard curve. The $T_{3}$ content of nuclear extracts from control, fasting, and hypothyroid animals as determined by RIA with our standard separation step was compared with values obtained with a charcoal separation step optimized according to the methods of Odell (33). The coefficient of variation for five samples determined by the two techniques was $<5 \%$.

For determining serum $T_{3}$ and $T_{4}$ concentrations, $1 \mathrm{~g} / \mathrm{dl}$ sodium salicylate was included in the assay buffer (31). Sample size was $10 \mu \mathrm{l}$ of serum in the $T_{3}$ RIA and $2 \mu \mathrm{l}$ in the $T_{4}$ RIA and an equivalent volume of thyroid hormone depleted rat serum (32) was added to the standard curves. Assay sensitivity was $\sim 1 \mathrm{pg}$ of $\mathrm{T}_{3}$ /tube and $5 \mathrm{pg}$ of $\mathrm{T}_{4} /$ tube.

TSH was assayed using materials kindly supplied by the National Institute of Arthritis, Digestive and Kidney Diseases by Dr. A. Parlow. Results are expressed in terms of the rat TSH RP-1 standard.

All results are given as mean \pm standard error (SE). Data were analyzed using the $t$ test for paired and unpaired values and twovariable linear regression analysis.

\section{Results}

Animals fasted for $72 \mathrm{~h}$ lost an average of $22 \%$ of their initial body weight compared with an $11 \%$ increase in weight of control animals. In addition, pituitary wet weight was $21 \%$ lower in fasted rats $(7.3 \pm 0.1 \mathrm{mg} /$ pituitary control vs. $5.8 \pm 0.1$ $\mathrm{mg} /$ pituitary fasting, $P<0.001)$ and total pituitary cytosolic protein content was decreased by $13 \%(P<0.1)$. The ratio of cytosolic protein to DNA content, however, was similar in control, fasting, and hypothyroid animals (mean value: $13.8 \pm 0.8$ $\mathrm{mg}$ of cytosolic protein/mg of DNA).

Serum $T_{3}, T_{4}, T S H$ levels. Serum total $\mathrm{T}_{3}, \mathrm{~T}_{4}$, and TSH levels for animals from the two experimental protocols are shown in Table I. In fasted animals (protocol I), serum $\mathrm{T}_{3}$ and $\mathrm{T}_{4}$ levels were decreased to 48 and $57 \%$ of control values, respectively. Fasting also resulted in a $48 \%$ reduction in serum TSH levels. In experiments involving hypothyroid and $\mathrm{T}_{4^{-}}$ injected animals (protocol II), serum $T_{3}$ and $T_{4}$ levels were lower in control rats than in the protocol I control animals ( $\mathrm{T}_{3} P<0.001, \mathrm{~T}_{4} P<0.025$ ) whereas TSH levels were higher $(P<0.05)$. In thyroidectomized animals serum $\mathrm{T}_{3}$ and $\mathrm{T}_{4}$ levels were decreased to 47 and $12 \%$ of control values whereas TSH levels were increased 10 -fold. In rats receiving $T_{4}$ injections, both serum levels of $T_{3}$ and $T_{4}$ were elevated approximately threefold whereas TSH levels were decreased by $83 \%$.

Technical aspects of saturation analysis. The kinetics of ${ }^{125} \mathrm{I}_{-} \mathrm{T}_{3}$ binding to isolated pituitary nuclei from euthyroid rats was investigated at both 22 and $37^{\circ} \mathrm{C}$. At $22^{\circ} \mathrm{C}$ (Fig. $1 \mathrm{~A}$ ), maximal binding occurred between 10 and $20 \mathrm{~h}$ of incubation and then declined. Approximately $8 \mathrm{~h}$ was required for $50 \%$
Table I. Serum $T_{3}, T_{4}$, and TSH Levels*

\begin{tabular}{llll}
\hline & $\mathrm{T}_{3}$ & $\mathrm{~T}_{4}$ & $\mathrm{TSH}$ \\
\hline & $n g / d l$ & $\mu g / d l$ & $n g / m l$ \\
Protocol I & & & \\
$\quad$ Control (15) & $77 \pm 5$ & $6.0 \pm 0.3$ & $282 \pm 40$ \\
Fasting (15) & $37 \pm 4 \ddagger$ & $3.4 \pm 0.3 \ddagger$ & $147 \pm 24 \S$ \\
Protocol II & & & \\
$\quad$ Control (13) & $49 \pm 3$ & $5.2 \pm 0.2$ & $449 \pm 57$ \\
Hypothyroid (14) & $23 \pm 2 \ddagger$ & $0.6 \pm 0.1 \ddagger$ & $4490 \pm 318 \ddagger$ \\
T $_{4}$-injected (9) & $131 \pm 18 \ddagger$ & $17.7 \pm 4.2^{11}$ & $76 \pm 21 \ddagger$ \\
& & & \\
\hline
\end{tabular}

* The data are presented as the mean \pm SE. $(n)=$ number of rats per group.

$\ddagger P<0.001$ compared with control.

$\S P<0.01$ compared with control.

" $P<0.02$ compared with control.

dissociation of bound ${ }^{125} \mathrm{I}_{-} \mathrm{T}_{3}$. After $3.5 \mathrm{~h}$ only $30 \%$ was dissociated. A comparably slow rate of dissociation $(25 \%$ at 3.5 h) was noted in vitro at $22^{\circ} \mathrm{C}$ when pituitary nuclei were labeled in vivo with "tracer" amounts of ${ }^{125} \mathrm{I}-\mathrm{T}_{3}$. With prolonged
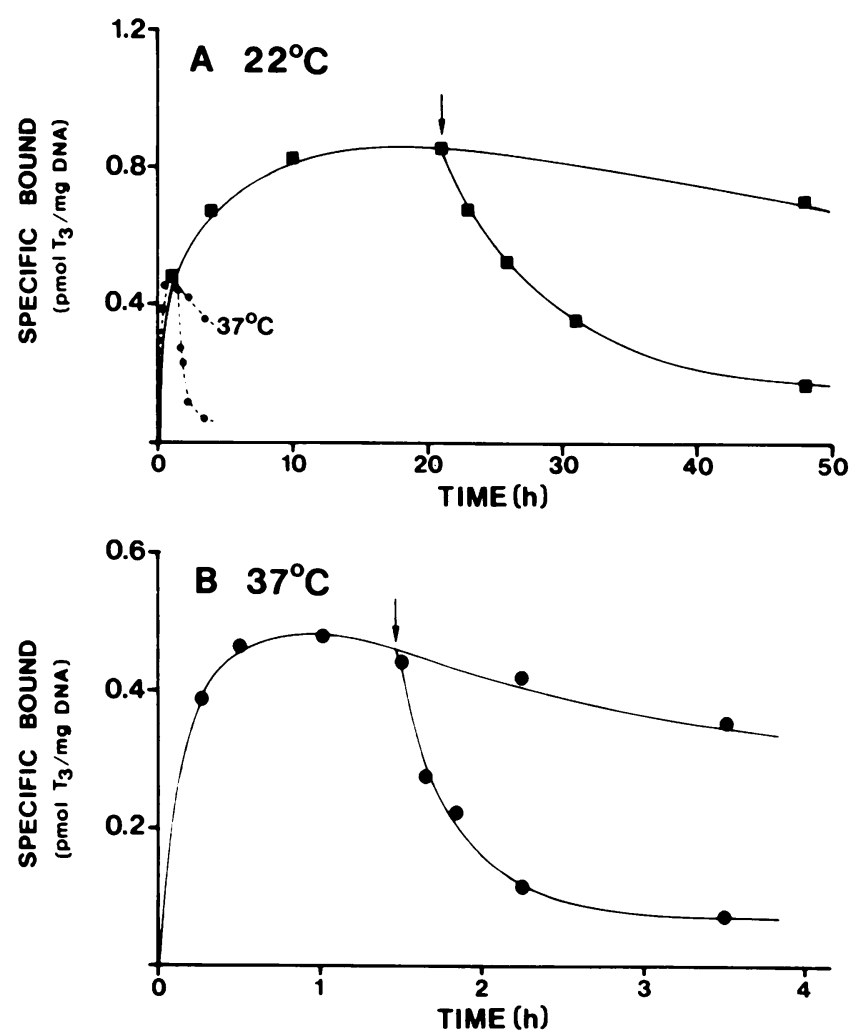

Figure 1. Time course of in vitro association/dissociation of ${ }^{125} \mathrm{I}_{-} \mathrm{T}_{3}$ with isolated pituitary nuclei from euthyroid rats. Anterior pituitary glands from 22 male rats $(200-225 \mathrm{~g}$ ) were pooled and a purified suspension of nuclei was prepared as described. Aliquots of the suspension were then incubated for varying periods of time with $10^{-10} \mathrm{M}^{125} \mathrm{I}_{-1} \mathrm{~T}_{3}$ at either $(A) 22^{\circ} \mathrm{C}$ or $(B) 37^{\circ} \mathrm{C}$. At the times indicated by the arrows, stable $\mathrm{T}_{3}$ (final concentration $5 \times 10^{-7} \mathrm{M}$ ) was added to some of the incubation tubes. NSB at both incubation temperatures was assessed by incubating aliquots of the nuclear suspension beginning at time zero with both ${ }^{125} \mathrm{I}_{-} \mathrm{T}_{3}$ and $5 \times 10^{-7} \mathrm{M}$ stable $\mathrm{T}_{3}$. The data at $37^{\circ} \mathrm{C}$ depicted in $(B)$ are reproduced in $(A)$ for comparison. 
in vitro incubation $(30-50 \mathrm{~h}), 80 \%$ of either the in vivo- or in vitro-bound ${ }^{125} \mathrm{I}-\mathrm{T}_{3}$ dissociated. Binding kinetics at $37^{\circ} \mathrm{C}$ were considerably more rapid (Fig. $1 \mathrm{~B}$ ); near-maximal binding was achieved after $30 \mathrm{~min}$ of incubation and only $20 \mathrm{~min}$ was required for $50 \%$ dissociation of bound hormone. Total binding at $37^{\circ} \mathrm{C}$, however, was only $56 \%$ of that at $22^{\circ} \mathrm{C}$ reflecting a temperature-dependent decrease in receptor affinity as well as probable greater receptor instability.

The slow dissociation rate at $22^{\circ} \mathrm{C}$ indicated that saturation studies carried out at this temperature for relatively brief incubation periods $(3.5 \mathrm{~h})$ would primarily determine unoccupied receptor sites. To confirm this, saturation experiments were performed in isolated pituitary nuclei from euthyroid animals injected 90 min prior to killing with a large dose of stable $\mathrm{T}_{3}\left(25 \mu \mathrm{g}\right.$ of $\mathrm{T}_{3} / 100 \mathrm{~g}$ of body $\left.\mathrm{wt}\right)$. As shown in Fig. 2 $A$, Scatchard analysis after $3.5 \mathrm{~h}$ of incubation revealed a very low, apparent maximum binding capacity $(\mathrm{MBC})$ in the $\mathrm{T}_{3^{-}}$ injected animals compared with vehicle-injected controls (MBC 0.2 vs. $1.4 \mathrm{pmol}_{3} / \mathrm{mg}$ DNA, respectively). More prolonged periods of incubation $(27 \mathrm{~h})$ resulted in higher apparent $\mathrm{MBC}$ values in nuclei from $\mathrm{T}_{3}$ injected animals (MBC $1.2 \mathrm{pmol} \mathrm{T}_{3} /$ mg DNA) demonstrating exchange of ${ }^{125} \mathrm{I}_{-} \mathrm{T}_{3}$ with endogenously bound hormone.

The possibility was considered that the low apparent MBC at $3.5 \mathrm{~h}$ of incubation observed in $\mathrm{T}_{3}$-injected animals was secondary to a high nuclear $T_{3}$ content, contributing substantial quantities of hormone to the in vitro saturation analysis. This would result in higher total $T_{3}$ concentrations and decreased ${ }^{125} \mathrm{I}_{-} \mathrm{T}_{3}$ binding. However, direct measurement of nuclear $\mathrm{T}_{3}$ by RIA revealed levels in $T_{3}$-injected animals of $\sim 3$ pmol $T_{3}$ / mg DNA, an amount that would increase the total mass of $T_{3}$ in the tubes containing the high concentrations of $T_{3}$ by $<10 \%$ and thus not significantly affect the MBC. The substantial increase in the apparent $\mathrm{MBC}$ at $27 \mathrm{~h}$ in $\mathrm{T}_{3}$-injected animals provides a further argument against an artifactual lowering of the MBC by this mechanism. In addition, the latter result precludes the possibility that the low apparent MBC noted after $3.5 \mathrm{~h}$ of incubation was due to a rapid decrease in receptor number in vivo after the $T_{3}$ injection.

Scatchard analysis of saturation experiments performed at an incubation temperature of $37^{\circ} \mathrm{C}$ (Fig. $2 \mathrm{~B}$ ) revealed a similar $\mathrm{MBC}$ in nuclei from animals injected either with vehicle or large doses of $T_{3}$, confirming the rapid dissociation rate noted in the kinetic experiments. However, despite complete dissociation of endogenous hormone at $37^{\circ} \mathrm{C}$, the $\mathrm{MBC}$ of $\sim 1$ pmol $\mathrm{T}_{3} / \mathrm{mg}$ DNA was not greater than that determined at $22^{\circ} \mathrm{C}$. This implied a significant and relatively rapid loss of receptor binding capacity at $37^{\circ} \mathrm{C}$.

In contrast to the effects of prolonged incubation at $22^{\circ} \mathrm{C}$ with nuclei from $\mathrm{T}_{3}$-injected animals, incubation of nuclei from vehicle-injected or euthyroid control animals for periods longer than $3.5 \mathrm{~h}$ did not significantly increase the MBC. As shown in Fig. 3, the apparent $\mathrm{MBC}$ in euthyroid nuclei increased from 0.98 to $1.15 \mathrm{pmol} \mathrm{T}_{3} / \mathrm{mg}$ DNA when in vitro incubation was extended from 1 to $3.5 \mathrm{~h}$ at $22^{\circ} \mathrm{C}$. This increase in $\mathrm{MBC}$ of $0.17 \mathrm{pmol} \mathrm{T}_{3} / \mathrm{mg}$ DNA correlates well with a predicted increase of $0.21 \mathrm{pmol} \mathrm{T}_{3} / \mathrm{mg}$ DNA given an endogenous nuclear $\mathrm{T}_{3}$ content of $\sim 1.4 \mathrm{pmol} \mathrm{T}_{3} / \mathrm{mg}$ DNA (discussed later) and the fact that $\sim 15 \%$ of the endogenously bound hormone should dissociate between 1 and $3.5 \mathrm{~h}$ of incubation. With a stable binding system, extension of the incubation period to $27 \mathrm{~h}$ should result in a further increase in the apparent $\mathrm{MBC}$ to $\sim 2.0 \mathrm{pmol} \mathrm{T}_{3} / \mathrm{mg}$ DNA. Such an increase, however, was not observed either in the experiment depicted in Fig. 3 or in three additional experiments where the effects of incubation time on $\mathrm{MBC}$ were investigated. Presumably greater degrees of $\mathrm{T}_{3}$ binding were not observed with the more prolonged incubation periods in euthyroid nuclei due to a relative balance between the rates of endogenous hormone dissociation and receptor degradation.

The results of the preceding experiments demonstrated that in vitro saturation techniques under the conditions employed could not accurately quantify total $T_{3}$ receptor capacity in isolated pituitary nuclei. However, the MBC determined from saturation studies carried out for relatively short incubation periods $(3.5 \mathrm{~h})$ at $22^{\circ} \mathrm{C}\left(\mathrm{MBC}_{22^{\circ}}\right)$ appeared to reflect reliably the unoccupied receptor capacity. Because $\sim 25 \%$ of endogenously bound hormone dissociates under these conditions, the following relationship was used to estimate the number of unoccupied receptor sites: unoccupied sites $=\mathrm{MBC}_{22^{\circ}}-(0.25)$ occupied sites. Thus, the number of unoccupied sites and, hence, total receptor capacity could be estimated using data from the in vitro saturation studies $\left(\mathrm{MBC}_{22^{\circ}}\right)$ and values obtained by RIA for nuclear $\mathrm{T}_{3}$ content.

Saturation studies at $22^{\circ} \mathrm{C}$. Scatchard analysis of saturation studies performed at $22^{\circ} \mathrm{C}$ for a $3.5-\mathrm{h}$ incubation period with
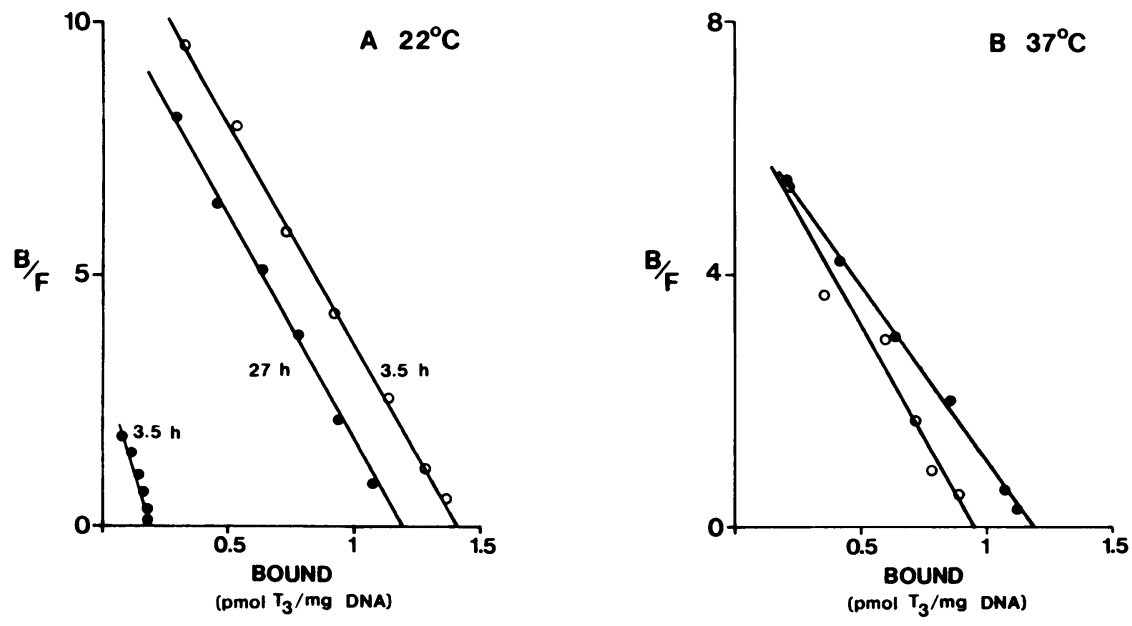

Figure 2. Scatchard analysis of in vitro binding data to isolated pituitary nuclei from euthyroid rats injected with a saturating dose of $\mathrm{T}_{3} .(A)$ Male rats (200-225 g) were injected intravenously $90 \mathrm{~min}$ before sacrifice with either 25 $\mu \mathrm{g}$ of stable $T_{3} / 100 \mathrm{~g}$ of body wt (15 animals) on an equal volume of vehicle (eight animals). Anterior pituitary glands from each group of rats were pooled, a suspension of isolated nuclei was prepared, and saturation analysis was performed at $22^{\circ} \mathrm{C}$ for either 3.5 or $27 \mathrm{~h}$. (B) Incubation at $37^{\circ} \mathrm{C}$ for $2 \mathrm{~h}$. Free concentrations are expressed in nanomolar. $\bullet, T_{3}$ injected; $O$, vehicle injected. 


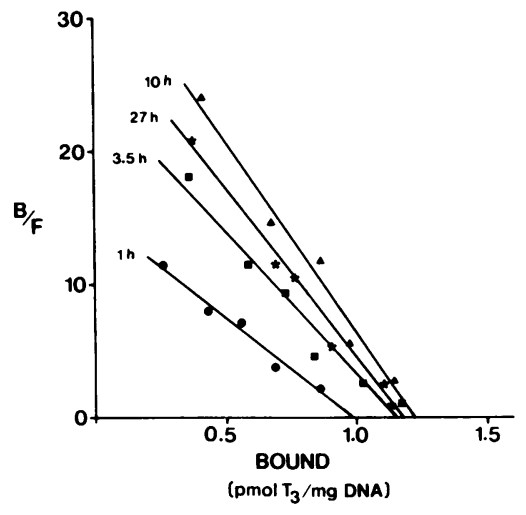

Figure 3. Effects of varying incubation time at $22^{\circ} \mathrm{C}$ on saturation analysis in isolated nuclei from euthyroid rats. Anterior pituitary glands from 32 male rats (200-225 g) were pooled, a suspension of isolated nuclei was prepared, and saturation analysis was performed at $22^{\circ} \mathrm{C}$ for $1,3.5,10$, or $27 \mathrm{~h}$. Values of $K_{\mathrm{d}}$ for each preparation are: $6.5 \times 10^{-11} \mathrm{M}(1 \mathrm{~h}), 4.7 \times 10^{-11} \mathrm{M}(3.5 \mathrm{~h}), 3.4 \times 10^{-11} \mathrm{M}(10 \mathrm{~h})$, and $3.9 \times 10^{-11} \mathrm{M}(27 \mathrm{~h})$. Free concentrations are expressed in nanomolar.

pituitary nuclei from all experimental groups revealed a single class of saturable, high-affinity binding sites. Representative experiments are shown in Fig. 4. As summarized in Table II, values of $\mathrm{MBC}_{22^{\circ}}$ obtained in control animals from protocol I were somewhat lower than control values noted in protocol II $(P<0.01)$. Fasting resulted in a $29 \%$ decrease in $\mathrm{MBC}_{22^{\circ}}$, a decrease similar to that noted in two groups of $\mathrm{T}_{4}$-injected animals. In hypothyroid animals, $\mathrm{MBC}_{22^{\circ}}$ was increased by $42 \%$. Values for the equilibrium dissociation constant $\left(K_{\mathrm{d}}\right)$ (Table II) were similar for all groups with a mean value of $7.2 \pm 0.75 \times 10^{-11} \mathrm{M}(n=18)$.

Nuclear $T_{3}$ content and estimation of total nuclear receptor capacity. Levels of receptor-bound endogenous $\mathrm{T}_{3}$ are shown in Table II. The nuclear $T_{3}$ content of control animals from protocol I experiments was significantly higher than that noted in the protocol II control group $(P<0.001)$; a finding consistent with the higher serum $T_{3}$ and $T_{4}$ levels and lower TSH levels seen in the former group. In fasted animals, nuclear $T_{3}$ levels were significantly decreased; however, the decrease was relatively modest $(\sim 15 \%)$ given the much larger decreases noted in serum $\mathrm{T}_{3}(52 \%)$ and serum $\mathrm{T}_{4}(43 \%)$ levels. Thyroidectomized animals demonstrated a $61 \%$ decrease in nuclear $\mathrm{T}_{3}$ content.

Because the $\mathrm{MBC}_{22^{\circ}}$ and nuclear $\mathrm{T}_{3}$ content data were obtained in different groups of experimental animals, the mean values of these parameters were utilized to calculate the unoccupied and total receptor binding capacities. As shown in Table II, these estimated values decreased 32 and 23\%, respectively, during fasting. Although the nature of the experimental data prevents a statistical analysis of these calculated figures, the fact that they are derived from two experimental data sets, each of which showed statistically significant decreases with fasting, strongly suggests that these calculated values are also of significance. Estimates of receptor occupancy revealed that $62 \%$ of binding sites were occupied in fasted animals compared with a $56 \%$ occupancy rate in protocol I controls. The significance of this increase in $T_{3}$ receptor occupancy accompanying fasting can again only be inferred from the fact that the $29 \%$ decrease in $\mathrm{MBC}_{22}$. in fasted rats was approximately twice the decrease noted in nuclear $T_{3}$ content. Thus the decrease in unoccupied and total receptor sites was relatively greater than the decrease in occupied sites suggesting an actual increase in receptor occupancy.

In hypothyroid animals, the number of unoccupied nuclear $\mathrm{T}_{3}$ binding sites was estimated to increase by $\sim 55 \%$ as compared with protocol II controls. Total binding capacity was also calculated to be slightly higher in hypothyroid animals ( 2.7 vs. $2.3 \mathrm{pmol} \mathrm{T}_{3} / \mathrm{mg}$ DNA, respectively). The fact, however, that nuclear $T_{3}$ levels decreased and $\mathrm{MBC}_{22^{\circ}}$ increased by comparable amounts in the thyroidectomized group $(0.5 \mathrm{pmol}$ $\mathrm{T}_{3} / \mathrm{mg}$ DNA decrease in nuclear $\mathrm{T}_{3}$ vs. $0.7 \mathrm{pmol} \mathrm{T}_{3} / \mathrm{mg}$ DNA increase in $\mathrm{MBC}_{22^{\circ}}$ ) suggests that total binding capacity is unaltered in hypothyroidism. As expected from the marked decrease in nuclear $T_{3}$ content, receptor occupancy in hypothyroid animals was considerably lower than in control animals. Although nuclear $T_{3}$ content was not determined in $T_{4}$-injected animals, one can estimate that given the marked decrease in $\mathrm{MBC}_{22^{\circ}}$ and assuming no change in total receptor number, nuclear occupancy in this group of animals would be $\sim 70 \%$.

Confirmation of these estimates of total receptor capacity was sought by performing saturation analysis under such in vitro conditions that would allow complete dissociation of endogenous hormone $\left(1-\mathrm{h}\right.$ incubation at $\left.37^{\circ} \mathrm{C}\right)$. In two experiments, fasting resulted in a $25 \%$ and $42 \%$ decrease in MBC. These values provide additional evidence that the decrease in total receptor capacity during fasting is relatively greater than the decrease in nuclear $T_{3}$ content and thus support the previous estimates of an actual increase in receptor occupancy. Similar experiments utilizing thyroidectomized animals demonstrated a $36 \%$ increase in MBC in one experiment and a $7 \%$ decrease in another, thus confirming that total receptor
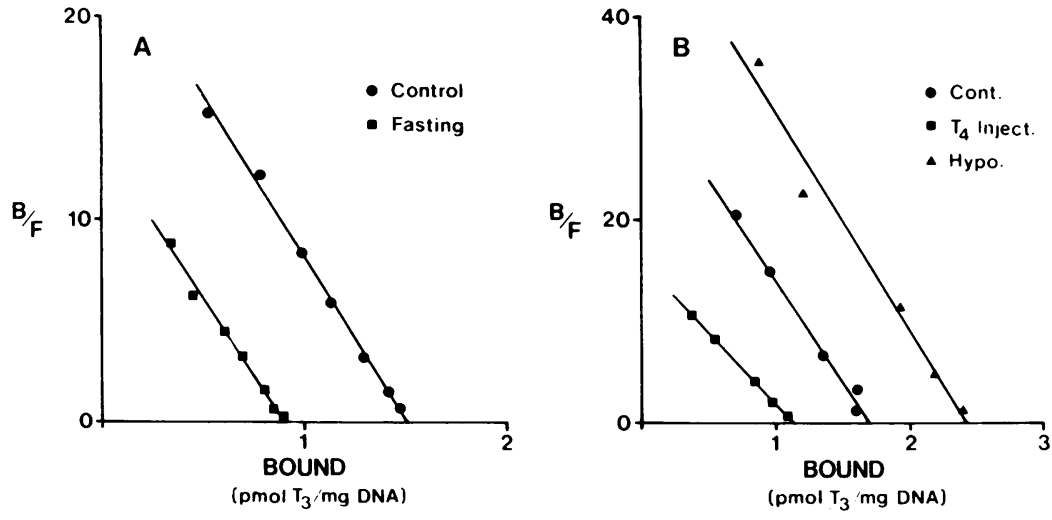

Figure 4. Scatchard analysis of in vitro binding data to isolated pituitary nuclei from $(A)$ control and fasting animals (protocol $\mathrm{I}$ ) and $(B)$ control, $\mathrm{T}_{4}$ injected, and thyroidectomized animals (protocol II). Anterior pituitaries from 4 to 11 animals in each experimental group were pooled, a suspension of isolated nuclei was prepared, and saturation analysis was performed at $22^{\circ} \mathrm{C}$ for $3.5 \mathrm{~h}$ of incubation. Free concentrations are expressed in nanomolar. 
Table II. Results of Saturation Analysis at $22^{\circ} \mathrm{C}$, Nuclear $T_{3}$ Content, and Estimation of Nuclear Receptor Capacity*

\begin{tabular}{|c|c|c|c|c|c|c|}
\hline & \multicolumn{2}{|c|}{ Saturation analysis } & \multirow[b]{2}{*}{ Nuclear $T_{3}$ content } & \multirow[b]{2}{*}{$\begin{array}{l}\text { Unoccupied } \\
\text { receptor capacity }\end{array}$} & \multirow[b]{2}{*}{$\begin{array}{l}\text { Total receptor } \\
\text { capacity }\end{array}$} & \multirow[b]{2}{*}{$\begin{array}{l}\text { Receptor } \\
\text { occupancy }\end{array}$} \\
\hline & $K_{d}$ & $\mathrm{MBC}_{22}$ & & & & \\
\hline & $\times 10^{-11} M$ & $p m o l T_{3} / m g ~ D N A$ & pmole $T_{3} / m g D N A$ & pmol $T_{3} / m g D N A$ & pmole $T_{3 /} / m g D N A$ & $\%$ \\
\hline \multicolumn{7}{|l|}{ Protocol I } \\
\hline Control & $7.1 \pm 1.1(7)$ & $1.48 \pm 0.04(7)$ & $1.43 \pm 0.06(8)$ & 1.11 & 2.54 & 56 \\
\hline Fasting & $8.0 \pm 2.0(3)$ & $1.05 \pm 0.08(3) \ddagger$ & $1.21 \pm 0.07(7) \S$ & 0.75 & 1.96 & 62 \\
\hline \multicolumn{7}{|l|}{ Protocol II } \\
\hline Control & $6.5 \pm 0.8(3)$ & $1.73 \pm 0.05(3)$ & $0.79 \pm 0.04(13)$ & 1.53 & 2.32 & 34 \\
\hline Hypothyroid & $4.4 \pm 0.5(3)$ & $2.45 \pm 0.17(3)^{\| \prime}$ & $0.33 \pm 0.07(6) \ddagger$ & 2.37 & 2.70 & 12 \\
\hline $\mathrm{T}_{4}$-injected & $7.1,15.0(2)$ & $1.13,1.16(2)$ & - & - & - & - \\
\hline
\end{tabular}

\footnotetext{
* Data are presented as mean $\pm \mathrm{SE}$. $(n)=$ number of experiments for $K_{\mathrm{d}}$ and $\mathrm{MBC}_{22}$ and number of animals for nuclear $\mathrm{T}_{3}$ content. Unoccupied receptor capacity calculated as $\mathrm{MBC}_{22^{\circ}}-(0.25)$ nuclear $\mathrm{T}_{3}$ content. Total receptor capacity calculated as nuclear $\mathrm{T}_{3}$ content + unoccupied receptor capacity. Receptor occupancy calculated as (nuclear $\mathrm{T}_{3}$ content $\div$ total receptor capacity) $\times 100$. Mean values of $\mathrm{MBC}_{22^{\circ}}$ and nuclear $\mathrm{T}_{3}$ content were used in these calculations. $¥ P<0.005$ compared with control. $\S P<0.05$ compared with control. Not included in the nuclear $\mathrm{T}_{3}$ content data for fasting animals is the value in one animal, which was greater than $3 \mathrm{SD}$ above the mean for the rest of the fasting group and greater than any value determined in the control group. Inclusion of this animal alters the mean fasting value very little (1.28 \pm 1.0 pmol $\left.\mathrm{T}_{3} / \mathrm{mg} \mathrm{DNA}\right)$; however, statistical significance is lost $(P=0.2)$. " $P<0.02$ compared with control.
}

number is either unchanged or somewhat increased in hypothyroid animals. The average value of the $K_{\mathrm{d}}$ determined by Scatchard analysis in these experiments was twice the value noted when saturation analysis was performed at $22^{\circ} \mathrm{C}$ $\left(14.2 \pm 1.53 \times 10^{-11} \mathrm{M}[n=8]\right.$ vs. $7.2 \pm 0.75 \times 10^{-11} \mathrm{M}[n$ = 18] respectively, $P<0.001)$.

$T_{4} 5^{\prime}$-deiodinase activity. The time course of $\mathrm{T}_{4} 5^{\prime}$-deiodination in the cytosol fraction of the homogenate from euthyroid pituitaries is shown in Fig. 5. The reaction rate was linear for the first $5 \mathrm{~min}$ of incubation and then slowly decreased. At 10,14 , and $30 \mathrm{~min}$, the reaction rates were 90,81 , and $61 \%$, respectively, of the initial velocity noted at $5 \mathrm{~min}$. Incubation times utilized in subsequent experiments were 14-15 $\mathrm{min}$ in control and fasted animals, $10 \mathrm{~min}$ in hypothyroid animals, and $30 \mathrm{~min}$ in $\mathrm{T}_{4}$-injected animals. These times were designed to minimize substrate utilization and yet allow for sufficient $\mathrm{T}_{3}$ accumulation for accurate measurement by RIA. Correction factors for these varying incubation times were not applied. In other experiments, aliquots of cytosol kept at $0-4^{\circ} \mathrm{C}$ maintained $>90 \%$ of activity for $1 \mathrm{~h}$. The coefficient of variation of

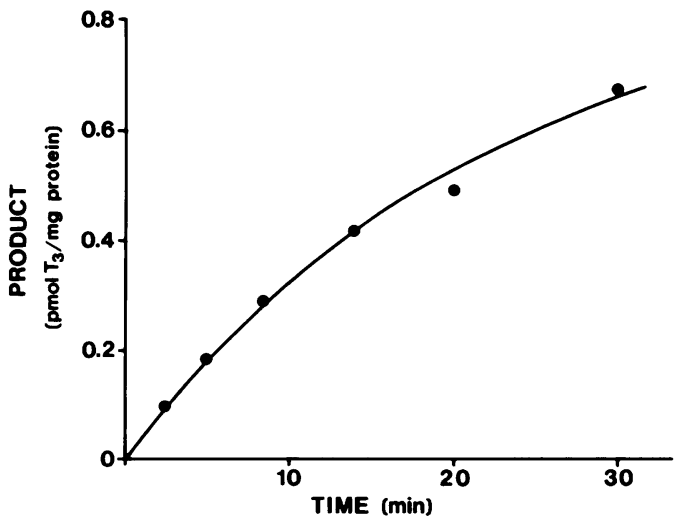

Figure 5. Time course of $T_{3}$ formation from $T_{4} 5^{\prime}$-deiodination in the cytosol fraction of euthyroid pituitary homogenates. Substrate concentrations were $9 \mathrm{nM} \mathrm{T}_{4}$ and $20 \mathrm{mM}$ DTT. Points represent the mean of duplicate determinations, which varied by $<10 \%$. replicate determinations at low substrate concentrations was $<15 \%$ and at high substrate concentrations $<10 \%$. The rate of $\mathrm{T}_{3}$ formation was found to increase linearly with homogenate protein concentration up to $6 \mathrm{mg} / \mathrm{ml}$. Protein content of the crude cytosolic preparation was typically $2-3 \mathrm{mg} / \mathrm{ml}$. Incubation of homogenates from both control and fasted animals with known concentrations of stable $T_{3}$ and $20 \mathrm{mM}$ DTT for 30 min at $37^{\circ} \mathrm{C}$ failed to disclose any evidence of $T_{3}$ degradation. No evidence of $\mathrm{T}_{3}$ formation was noted in cytosol fractions that were either heated to $80^{\circ} \mathrm{C}$ for $45 \mathrm{~min}$ or were not enriched with DTT.

Using substrate concentrations of $1.4-100 \mathrm{nM} \mathrm{T}_{4}$ and 20 mM DTT, 5'-deiodination of $T_{4}$ displayed simple saturation kinetics. Eadie-Hofstee plots (Fig. 6) revealed apparent Michaelis constant $\left(K_{\mathrm{m}}\right)$ values of $\sim 4 \mathrm{nM}$ in both control and fasting animals, reflecting the low $K_{\mathrm{m}}$ (type II) $5^{\prime}$-deiodinase component responsible for the majority of $T_{4}$ to $T_{3}$ conversion

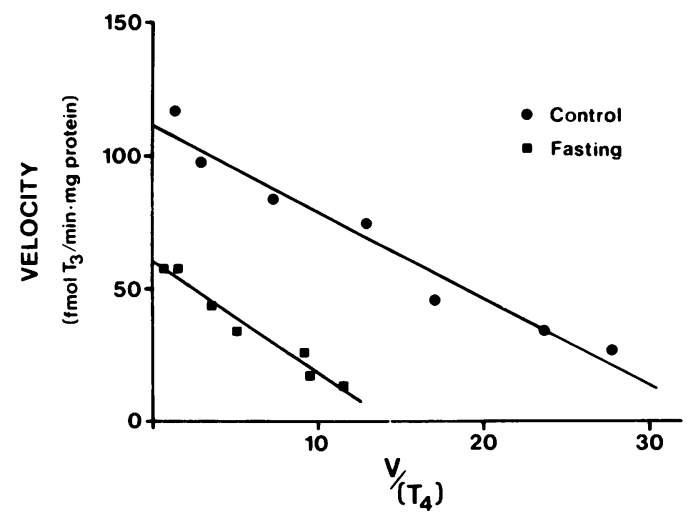

Figure 6. Kinetic analysis of pituitary $\mathrm{T}_{4} 5^{\prime}$-deiodinase activity in control and fasting rats by use of the Eadie-Hofstee plot. Aliquots of the pooled cytosol fraction from pituitary homogenates were incubated with 1.4-100 $\mathrm{nM} \mathrm{T}_{4}$ and $20 \mathrm{mM}$ DTT for 14-15 min. $\mathrm{T}_{3}$ formation was then quantified in ethanol extracts of the reaction mixture by RIA. $T_{4}$ concentrations are expressed in nanomolar. 
in the pituitary (34). As shown in Table III, fasting was associated with a $37 \%$ decrease $(P<0.025)$ in maximal enzyme activity $\left(V_{\max }\right)$. In hypothyroid animals, $V_{\max }$ increased approximately ninefold, whereas in $\mathrm{T}_{4}$-injected animals, $5^{\prime}$-deiodinase activity was reduced to $\sim 10 \%$ of the value seen in control animals.

\section{Discussion}

The principal goal of the present study was to compare the intracellular factors affecting thyroid hormone action in the pituitary during the fasting and hypothyroid states. Because the interaction of $T_{3}$ with specific, high-affinity nuclear-binding sites appears to represent an important event in the control of TSH secretion (35-37), we sought to quantify pituitary $T_{3^{-}}$ generating activity and the number and degree of occupancy of nuclear thyroid hormone receptors. The application of in vitro receptor-binding techniques to isolated pituitary nuclei was complicated significantly by receptor occupancy with endogenous hormone, slow dissociation of the hormonereceptor complex at $22^{\circ} \mathrm{C}$, and receptor instability at both 22 and $37^{\circ} \mathrm{C}$. This combination of factors can obviously result in serious misinterpretation of in vitro binding data. The attainment of a plateau in the association curve, as demonstrated between 10 and $21 \mathrm{~h}$ at $22^{\circ} \mathrm{C}$ and 30 and $90 \mathrm{~min}$ at $37^{\circ} \mathrm{C}$ (Fig. 1), is clearly insufficient evidence that both stability and equilibrium conditions exist so that total receptor capacity can be determined accurately by Scatchard analysis.

The justification for applying Scatchard analysis in these experiments where nonsteady-state conditions exist is based on the rapid attainment of equilibrium with the unoccupied receptor fraction. As discussed by Aranyi (38) and Yeakley et al. (39), lack of equilibrium with unoccupied binding sites results primarily in underestimation of receptor affinity with only minimal error in the determination of unoccupied binding capacity. The high receptor affinity noted at $22^{\circ} \mathrm{C}\left(K_{\mathrm{d}} \sim 7\right.$ $\times 10^{-11} \mathrm{M}$ ), as well as the lack of significant change in the $K_{\mathrm{d}}$ when incubation is extended from 3.5 to $27 \mathrm{~h}$ (Fig. 3), strongly suggests that equilibrium with unoccupied receptor sites occurs rapidly.

A somewhat surprising finding in this study was the significant differences noted between protocol I and protocol

Table III. Pituitary $T_{4}$ 5'-Deiodinase Activity*

\begin{tabular}{lll}
\hline & $K_{\mathrm{m}}$ & $V_{\max }$ \\
\hline & $n M$ & fmol $T_{3} /$ min $\cdot m g$ prot \\
Protocol I & & \\
Control (4) & $4.3 \pm 0.5$ & $95 \pm 11$ \\
Fasting (5) & $4.0 \pm 0.4$ & $60 \pm 6 \S$ \\
Protocol II & & \\
Control (3) & $5.2 \pm 1.2$ & $57 \pm 9$ \\
Hypothyroid (3) & $7.0 \pm 1.8$ & $491 \pm 59^{\prime \prime}$ \\
T $_{4}$-injected (2) & - & 7,3
\end{tabular}

* Data are presented as mean \pm SE. $(n)=$ number of experiments.

$¥$ Velocity values for $T_{4}$-injected animals were determined at a single $\mathrm{T}_{4}$ concentration of $100 \mathrm{nM}$. Enzyme activity was too low to permit determination of $K_{\mathrm{m}}$.

$\S P<0.025$ vs. control.

" $P<0.005$ vs. control.
II control groups in essentially all experimental parameters. These differences were not due to interassay variation in that values for the various serum parameters for all experimental groups were determined in the same assays. In addition, experimental values for control groups within a single protocol were remarkably consistent as shown in Tables I-III. Although experiments involving animals in protocols I and II were not performed on the same day, experiments were frequently carried out concurrently, and thus there was no significant difference in the time frame of data acquisition. Of possible importance, however, is the fact that protocol I control animals were somewhat younger at the time of sacrifice than protocol II controls (8 wk vs. $11 \mathrm{wk}$, respectively) and were housed under potentially more stressful conditions (as discussed earlier). These factors may have contributed to the differences observed in the experimental data between the two groups.

Experimental findings and physiologic implications. Although thyroid hormones are of unquestionable importance in controlling various pituitary functions, the cellular mechanisms mediating these effects remain poorly understood. Recent evidence suggests that the regulatory effects of $T_{3}$ on TSH secretion may be related to the degree of occupancy of pituitary nuclear $\mathrm{T}_{3}$ receptors (35-37). Our finding that hypothyroidism is accompanied by a $61 \%$ decrease in nuclear $T_{3}$ content and a marked decrease in receptor occupancy is consistent with this hypothesis and confirms work by previous investigators $(28,40)$. In fasted rats, however, a strikingly different situation is seen despite significant decreases in both serum $T_{3}$ and $T_{4}$ concentrations. Thus, although nuclear $T_{3}$ levels in starved animals are also decreased, the decrease is relatively modest (15\%) and when combined with the $23 \%$ reduction in total binding capacity, receptor occupancy appears to be unchanged or actually increased relative to control values. If indeed receptor occupancy (irrespective of total receptor number) is the key parameter mediating thyroid hormone regulation of TSH secretion, then the present results offer a plausible explanation for the failure of TSH levels to rise during shortterm fasting in the rat. Support for this concept can be obtained from the present studies. For the five experimental groups examined, an excellent correlation was noted between the estimated receptor occupancy and the mean serum TSH levels as shown in Fig. $7(r=-0.97, P<0.01)$. Although other factors not specifically addressed in these studies, such as alterations in hypothalamic secretion or postreceptor events mediated directly by fasting, may also be important in the response of the pituitary to starvation, the maintenance of relatively normal nuclear $T_{3}$ levels and normal to increased receptor occupancy are likely to be important contributing factors to the observed suppression in circulating TSH levels.

Our data regarding thyroid hormone economy in the pituitary during fasting are in sharp contrast to the findings reported by others in the liver (8). Thus, short-term starvation in the rat is accompanied by profound decreases in hepatic nuclear $T_{3}$ levels which, despite a decrease in total receptor number, result in a significantly decreased receptor occupancy rate $(8,41,42)$. Accompanying these observed changes are metabolic alterations in the liver and other peripheral tissues that appear to be due in part to decreased thyroid hormone action $(1,6,9-11,17,43)$. In this regard, the decrease in hepatic $\mathrm{T}_{4} 5^{\prime}$-deiodinase activity (high $K_{\mathrm{m}}$, type $\mathrm{I}$ ) noted in fasting (44) is similar to that occurring in hypothyroidism (22) and can largely be reversed by the administration of thyroid 


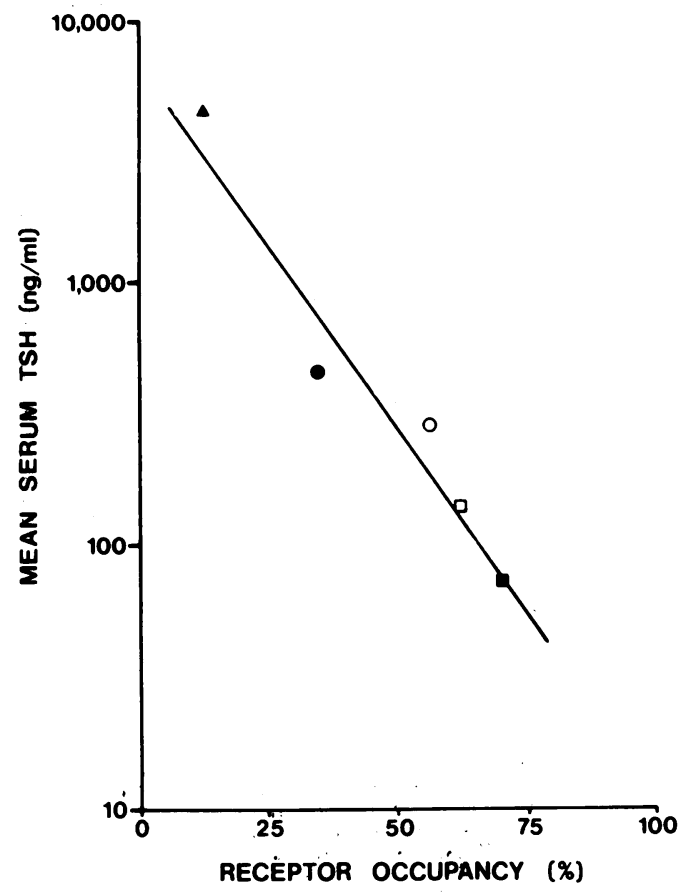

Figure 7. Mean serum TSH concentrations plotted as a logarithmic function of the estimated $T_{3}$, receptor occupancy for the five experimental groups. Receptor occupancy in $T_{4}$-injected animals was calculated by assuming a total receptor number equal to that in protocol II control animals. Contról I, O; fasting, $\square$; control II, •; hypothyroid, ム; $\mathrm{T}_{4}$-injected, $\mathbf{a} ; r=-0.97, P<0.01$.

hormone during the fasting period $(45,46)$. In contrast, the decreased pituitary $\mathrm{T}_{4} 5^{\prime}$-deiödinase activity (low $K_{\mathrm{m}}$, type II) noted in the present study is qualitatively similar to that seen in the $\mathrm{T}_{4}$-injected animals (21) and thus suggests an enhanced action of thyroid hormone on the hypophysis during fasting, a formulation that is consistent with the observed decreases in serum TSH levels and the increases noted in nuclear receptor occupancy.

The factors responsible for the maintenance of near normal pituitary nuclear $T_{3}$ levels in the fasted rat are uncertain but of potentially great physiologic importance. Although in vivo rates of $T_{4}$ to $T_{3}$ conversion were not determined in the present study, one can infer from the observed decreases in serum $\mathrm{T}_{4}$ levels and in vitro $5^{\prime}$-deiodinase activity that "local" $\mathrm{T}_{3}$ generation by the pituitary as a whole is diminished during fasting. Mechanisms that could serve to "protect" nuclear $T_{3}$ levels in the fasting state include an increase in the rate of cellular or nuclear $T_{3}$ entry, a decrease in the fractional rate of cellular $T_{3}$ degradation, or a decrease in the turnover rate of occupied $\dot{T}_{3}$ receptors. Additional studies will be required to address these possibilities.

Comparison with prior studies. A comparison of the present data with previous studies reveals apparent discrepancies in the values for $T_{3}$ receptor number and occupancy. Others, by using in vivo saturation techniques, have estimated that the binding capacities of euthyroid and hypothyroid rat pituitary nuclei are 1.2 and 1.5 pmol $\mathrm{T}_{3} / \mathrm{mg}$ DNA, respectively $(18,36$, 47), values that are $50 \%$ lower than those determined in the present study. Similar discrepancies have been noted between data obtained in vivo and in vitro in cerebral cortex (48). Although the reasons for these differences are uncertain, several possibilities exist. An important assumption inherent to the in vivo technique is that equilibration has been achieved between serum and nuclear $\mathrm{T}_{3}$ (49). Recent evidence, however, suggests that the entry of $T_{3}$ to both the cytoplasm and the nucleoplasm may be a receptor-mediated, saturable process $(50-52)$. Thus significant intracellular free $T_{3}$ gradients may exist (52) and equilibration between serum, cytoplasm, and nucleus may be delayed at the higher serum $\mathrm{T}_{3}$ levels employed during in vivo saturation studies. Furthermore, given that the time for $50 \%$ dissociation of the $T_{3}$-receptor complex in vivo may be as

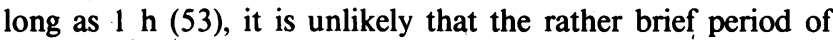
time during the in vivo analysis when serum and nuclear ${ }^{125} \mathrm{I}$ $\mathrm{T}_{3}$ levels are in steady state is sufficient for a true equilibrium to occur with previously occupied receptors. Given these uncertainties, it is possible that the two-compartment model (54), which forms the basis for the in vivo saturation techniques, represents an oversimplification and results in the measurement of only a fraction of the total complement of nuclear receptors. Alternatively, it is possible that the procedures utilized herein in preparing the nuclei for the in vitro studies expose additional nuclear $\mathrm{T}_{3}$-binding sites not available for in vivo binding. This appears unlikely, however, because in vivo injection of a large dose of $\mathrm{T}_{3}$ reduced $\mathrm{MBC}_{22^{\circ}}$ to a very low value (Fig. $2 \dot{A}$ ), indicating complete receptor saturation. Regardless of the reasons for these differences, however, our finding of a significant number of unoccupied binding sites in hyperthyroid animals (Table II) and a large discrepancy in apparent MBC (after $3.5 \mathrm{~h}$ of incubation) in nuclei from vehicle-injected and in vivo $\mathrm{T}_{3}$-saturated animals (Fig. $2 \mathrm{~A}$ ) strongly suggests that endogenous pituitary receptor occupancy in the euthyroid rat is less than the $78 \%$ value reported by Silva et al. (55), who úsed in vivo techniques.

The application of in vitro saturation techniques to pituitary tissue has been limited (56). Recently, Coulombe et al. (57) and von Overbeck and Lemarchand-Beraud (58) have reported a significant decrease in the number of solubilized pituitary nuclear $T_{3}$ receptors in adult hypothyroid rats; an observation that is in marked contrast to the present data and that noted previously by Silva and Larsen (36), who used in vivo techniques and by Samuels et al. (59) in $T_{3}$-depleted growth hormone $\left(\mathrm{GH}_{1}\right)$ cells. Neither Coulombe et al. (57) or von Overbeck and Lemarchand-Beraud (58), however, adequately address the issues of receptor stability, association/dissociation rates, establishment of equilibrium with endogenously occupied sites, or efficiency of the receptor extraction technique. Indeed, it appears likely, from data presented by the latter investigators, that the solubilization methods employed preferentially extract occupied $\mathrm{T}_{3}$-binding sites: Furthermore, Seelig et al. (60) have recently demonstrated that binding of $T_{3}$ to solubilized hepatic nuclear receptors at $0-4^{\circ} \mathrm{C}$ does not follow a reversible bimolecular process, thereby making Scatchard analysis of such data invalid. Methodologic problems inherent to the study of salt-solubilized receptors are thus a possible explanation for the descrepancies noted above.

Pituitary 5 -deiodinase activity in fasted animals has been reported to be unchanged $(19,20)$ or decreased $(21,22)$. Previous investigators, however, by using a single relatively high concentration of $\mathrm{T}_{4}(\sim 1 \mu \mathrm{M})$ during in vitro assay, have not been able to distinguish between high $K_{\mathrm{m}}$ (type I) and low $K_{\mathrm{m}}$ (type II) 5'-deiodinase activity. The kinetic data presented herein clearly demonstrate that fasting is accompanied by a significant decrease in $V_{\max }$ for the low $K_{\mathrm{m}} 5^{\prime}$-deiodinase 
pathway with no change in $K_{\mathrm{m}}$. This finding is in sharp contrast to the marked elevations in low $K_{\mathrm{m}} 5^{\prime}$-deiodinase activity noted in hypothyroid animals and suggests that factors in addition to peripheral thyroid hormone levels are involved in regulating this physiologically important enzymatic process.

The relevance of our findings in whole pituitary homogenates to the subset of TSH-producing cells is at present uncertain. Nevertheless, our data demonstrate that, in the fasting state, alterations occur in thyroid hormone economy in the pituitary, which serve to maintain relatively normal amounts of nuclear receptor bound $T_{3}$ and may result in an actual increase in receptor occupancy. We hypothesize that this mechanism may be responsible, at least in part, for the observed suppression of TSH secretion that accompanies shortterm starvation in the rat.

\section{Acknowledgments}

The authors thank Dr. P. Reed Larsen for the generous gift of the $T_{3}$ and $T_{4}$ antiserum and Dr. Robert A. Adler for his continued support and encouragement.

This research was supported by the National Institutes of Health grant HD-09020. During the course of these studies Dr. St. Germain was the recipient of the Tiffany-Blake Fellowship from the Hitchcock Foundation and a National Research Service Award Fellowship (5 F32 AM-06777)

\section{References}

1. Wartofsky, L., and K. D. Burman. 1982. Alterations in thyroid function in patients with systemic illness: "the euthyroid sick syndrome." Endocr. Rev. 3:164-217.

2. Campbell, G. A., M. Kurcz, S. Marshall, and J. Meites. 1977. Effects of starvation in rats on serum levels of follicle stimulating hormone, luteinizing hormone, thyrotropin, growth hormone, and prolactin: response to $\mathrm{LH}$-releasing hormone and thyrotropin releasing hormone. Endocrinology. 100:580-587.

3. Palmblad, J., L. Levi, A. Burger, A. Melander, U. Westgren, H. von Schenck, and G. Skude. 1977. Effects of total energy withdrawal (fasting) on the levels of growth hormone, thyrotropin, cortisol, adrenaline, noradrenaline, $\mathrm{T}_{4}, \mathrm{~T}_{3}$, and $\mathrm{rT}_{3}$ in healthy males. Acta Med. Scand. 201:15-22.

4. Beaumont, P. J., G. C. George, B. L. Pimstone, and A. I. Vinik. 1976. Body weight and the pituitary response to hypothalamic releasing hormones in patients with anorexia nervosa. J. Clin. Endocrinol. Metab. 43:487-496.

5. Azizi, F. 1978. Effect of dietary composition on fasting-induced changes in serum thyroid hormones and thyrotropin. Metab. Clin. Exp. 27:935-942.

6. Gardner, D. F., M. M. Kaplan, C. A. Stanley, and R. D. Utiger. 1979. Effect of tri-iodothyronine replacement on the metabolic and pituitary responses to starvation. N. Engl. J. Med. 300:579-584.

7. Harris, A. R. C., S. Fang, F. Azizi, L. Lipworth, A. G. Vagenakes, and L. E. Braverman. 1978. Effect of starvation on hypothalamicpituitary-thyroid function in the rat. Metab. Clin. Exp. 27:1074-1083.

8. Oppenheimer, J. H., and H. L. Schwartz. 1980. Factors determining the level of activity of 3,5,3'-triiodothyronine-responsive hepatic enzymes in the starved rat. Endocrinology. 107:1460-1468.

9. Carter, W. J., K. N. Shakir, S. Hodges, F. H. Faas, and J. O. Wynn. 1975. Effect of thyroid hormone on metabolic adaptation to fasting. Metab. Clin. Exp. 24:1177-1183.

10. Burman, K. D., L. Wartofsky, R. E. Dinterman, P. Kelser, and R. W. Wannemacher, Jr. 1979. The effect of $T_{3}$ and reverse $T_{3}$ administration on muscle protein catabolism during fasting as measured by 3-methylhistidine excretion. Metab. Clin. Exp. 28:805-813.
11. Cahill, G. S. 1981. Role of $T_{3}$ in fasted men. Life Sci. 28: 1721-1726.

12. Henson, L. C., and D. Herber. 1983. Whole body protein breakdown rates and hormonal adaptation in fasted obese subjects. $J$. Clin. Endocrinol. Metab. 57:316-319.

13. Jackson, C. M. 1916. Effect of inanition upon the structure of the thyroid and parathyroid gland of the albino rat. Am. J. Anat. 19: 305-352.

14. Chopra, I. J., H. E. Carlson, and D. H. Solomon. 1978. Comparison of inhibitory effects of 3,5,3'-triiodothyronine $\left(T_{3}\right)$, thyroxine $\left(\mathrm{T}_{4}\right), 3,3^{\prime}, 5^{\prime}$-triiodothyronine $\left(\mathrm{rT}_{3}\right)$, and 3,3'-diiodothyronine $\left(\mathrm{T}_{2}\right)$ on thyrotropin-releasing hormone-induced release of thyrotropin in the rat in vitro. Endocrinology. 103:393-402.

15. Burman, K. D., R. C. Smallridge, J. R. Burge, D. Carlson, and L. Wartofsky. 1983. Ipodate restores the fasting-induced decrement in thyrotropin secretion. J. Clin. Endocrinol. Metab. 57:597-602.

16. Hugues, J. N., A. Reinberg, D. Jordan, J. Sebaoun, E. Modigliani, and A. G. Burger. 1982. Effects of starvation on circadian variation of plasma TSH in rats. Acta Endocrinol. 101:403-407.

17. Carr, F. E., S. Seelig, C. N. Marish, H. L. Schwartz, and J. H. Oppenheimer. 1983. Starvation and hypothyroidism exert an overlapping influence on rat hepatic messenger RNA activity profiles. J. Clin. Invest. 72:154-163.

18. Bavli, S. Z. 1980. Fasting, but not glucagon administration, decreases anterior pituitary nuclear thyroid hormone receptors in rats. Metab. Clin. Exp. 29:636-642.

19. Cheron, R. G., M. M. Kaplan, and P. R. Larsen. 1979. Physiological and pharmacological influences on thyroxine to 3,5,3'triiodothyronine conversion and nuclear 3,5,3'-triiodothyronine binding in rat anterior pituitary. J. Clin. Invest. 64:1402-1414.

20. Gavin, L. A., and M. Moeller. 1983. Somatostatin inhibits rat $\mathrm{T}_{4}-5^{\prime}$-deiodinase. J. Clin. Invest. 72:2020-2030.

21. Kaplan, M. M. 1980. Thyroxine 5'-monodeiodination in rat anterior pituitary homogenates. Endocrinology. 106:567-576.

22. Naito, K., M. Inada, Y. Mashio, K. Tanaka, H. Ishii, M. Nishikawa, and $\mathrm{H}$. Imura. 1981. Modulation of $\mathrm{T}_{4} 5^{\prime}$-monodeiodination in rat anterior pituitary and liver homogenates by thyroid states and fasting. Endocrinol. Jpn. 28:793-798.

23. Spindler, B. J., K. M. MacLeod, J. Ring, and J. D. Baxter. 1975. Thyroid hormone receptors: binding characteristics and lack of hormonal dependency for nuclear localization. J. Biol. Chem. 250: 4113-4119.

24. Burton, K. 1956. A study of the conditions and mechanism of the diphenyl amine reaction for the colorimetric estimation of deoxynucleic acid. Biochem. J. 62:315-323.

25. Galton, V. A. 1980. Binding of thyroid hormones in vivo by hepatic nuclei of Rana catesbeiana tadpoles. Endocrinology. 106:859866.

26. Scatchard, G. 1949. The attractions of proteins for small molecules and ions. Ann. NY Acad. Sci. 51:660-672.

27. Munck, A. 1976. General aspects of steroid hormone-receptor interactions. In Receptors and Mechanism of Action of Steroid Hormones, Part I. J. R. Pasqualini, editor. Marcel Dekker, Inc., New York. 1-40.

28. Larsen, P. R., S. Z. Bavli, M. Castonguay, and R. Jove. 1980. Direct radioimmunoassay of nuclear 3,5,3'-triiodothyronine in rat anterior pituitary. J. Clin. Invest. 65:675-681.

29. Lowry, O. H., N. J. Rosebrough, A. L. Farr, and R. J. Randall. 1951. Protein measurement with the Folin phenol reagent. J. Biol. Chem. 193:265-275.

30. Dowd, J. E., and D. S. Riggs. 1965. A comparison of estimates of Michaelis-Menton kinetic constants from various linear transformations. J. Biol. Chem. 240:863-869.

31. Larsen, P. R. 1972. Direct immunoassay of triiodothyronine in human serum. J. Clin. Invest. 51:1939-1949.

32. Samuels, H. H., F. Stanley, and J. Casanova. 1979. Depletion of L-3,5,3'-triiodothyronine and L-thyroxine in euthyroid calf serum 
for use in cell culture studies of the action of thyroid hormone. Endocrinology. 105:80-85.

33. Odell, W. D. 1980. Use of charcoal to separate antibody complexes from free ligand in radioimmunoassay. Methods Enzymol. 70:274-279.

34. Visser, T. J., M. M. Kaplan, J. L. Leonard, and P. R. Larsen. 1983. Evidence for two pathways of iodothyronine $5^{\prime}$-deiodination in rat pituitary that differs in kinetics, propylthiouracil sensitivity, and response to hypothyroidism. J. Clin. Invest. 71:992-1002.

35. Silva, J. E., and P. R. Larsen. 1977. Pituitary nuclear 3,5,3'triiodothyronine and thyrotropin secretion: an explanation for the effect of thyroxine. Science (Wash. DC). 198:617-620.

36. Silva, J. E., and P. R. Larsen. 1978. Contributions of plasma triiodothyronine and local thyroxine monodeiodination to triiodothyronine to nuclear triiodothyronine receptor saturation in pituitary, liver, and kidney of hypothyroid rats. J. Clin. Invest. 61:1247-1259.

37. Gershengorn, M. C. 1983. Thyroid hormone regulation of thyrotropin production and interaction with thyrotropin releasing hormone in thyrotropic cells in culture. In Molecular Basis of Thyroid Hormone Action. J. H. Oppenheimer and H. H. Samuels, editors. Academic Press, Inc., New York. 387-412.

38. Aranyi, P. 1980. Theoretical considerations in assessing steroid hormone-receptor interactions: how do slow kinetics influence the results of equilibrium measurements? In Hormones and Cancer. S. Iacobelli, R. J. B. King, H. R. Lindner, and M. E. Lippman, editors. Raven Press, New York. 217-226.

39. Yeakley, J. M., K. Balasubramanian, and R. W. Harrison. 1980. Comparison of glucocorticoid-receptor binding kinetics with predictions from a bimolecular model. J. Biol. Chem. 255:4182-4188.

40. van Doorn, J., D. van der Heide, and F. Roelfsema. 1983. Sources and quantity of 3,5,3'-triiodothyronine in several tissues of the rat. J. Clin. Invest. 72:1778-1792.

41. DeGroot, L. J., A. H. Coleoni, P. A. Rue, H. Seo, E. Martino, and S. Refetoff. 1977. Reduced nuclear triiodothyronine receptors in starvation-induced hypothyroidism. Biochem. Biophys. Res. Commun. 79:173-178.

42. DeGroot, L. J., J. Torresani, P. Carrayon, and A. Tirard. 1976. Factors influencing triiodothyronine binding properties of liver nuclear receptors. Acta Endocrinol. 83:293-304.

43. Dillmann, W. H., and C. Lehman. 1983. A physiological $T_{3}$ dose normalizes the level of specific cardiac mRNAs in rats on restricted food intake. Program of the 59th annual meeting of the American Thyroid Association, New Orleans, LA. T-36. (Abstr.)

44. Gavin, L. A., F. Bui, F. McMahon, and R. R. Cavalieri. 1980. Sequential deiodination of thyroxine to $3,3^{\prime}$-diiodothyronine via $3,5,3^{\prime}$ triiodothyronine and 3,3',5'-triiodothyronine in rat liver homogenate: the effects of fasting versus glucose feeding. J. Biol. Chem. 254:49-53.

45. Chopra, I. J. 1980. Alterations in monodeiodination of iodothyronines in the fasting rat: effect of reduced nonprotein sulfhydryl groups and hypothyroidism. Metab. Clin. Exp. 29:161-167.
46. Balsam, A., F. Sexton, and S. H. Ingbar. 1981. Effects of dietary manipulation on the in vitro generation of 3,5,3'-triiodothyronine from thyroxine in rat liver preparations. Life Sci. 28:1727-1736.

47. Oppenheimer, J. H., H. L. Schwartz, and M. I. Surks. 1974. Tissue differences in the concentration of triiodothyronine nuclear binding sites in the rat: liver, kidney, pituitary, heart, brain, spleen, and testes. Endocrinology. 95:897-903.

48. Kolodny, J., P. R. Larsen, and J. E. Silva. 1983. In vitro $T_{3}$ binding to rat cerebrocortical neuronal and glial nuclei suggests the presence of binding sites unavailable in vivo. Program of the 59th annual meeting of the American Thyroid Association, New Orleans, LA. T-62. (Abstr.)

49. Oppenheimer, J. H., H. L. Schwartz, D. Koerner, and M. I. Surks. 1974. Limited binding capacity sites for L-triiodothyronine in rat liver nuclei. J. Clin. Invest. 53:768-777.

50. Cheng, S. 1983. Characterization of binding and uptake of 3,5,3'-triiodo-L-thyronine in cultured mouse fibroblasts. Endocrinology. 112:1754-1762.

51. Eckel, J., G. S. Rao, M. L. Rao, and H. Breuer. 1979. Uptake of L-tri-iodothyronine by isolated liver cells. Biochem. J. 182:473-491.

52. Oppenheimer, J. H., and H. L. Schwartz. 1983. Stereospecific transport channels between plasma and cytosol and between cytosol and nuclei in rat tissues. Program of the 65th annual meeting of the Endocrine Society, San Antonio, TX. 481. (Abstr.)

53. Thrall, C. L., and T. Yanagihara. 1982. Alterations in nuclear thyroid hormone receptors in cerebral cortex in vivo. J. Neurochem. 38:669-674.

54. Pearson, J. D., N. Veall, and H. Vetter. 1958. A practical method for plasma albumin turnover studies. Strahlentherapie. 38: 290-297.

55. Silva, J. E., T. E. Dick, and P. R. Larsen. 1978. The contribution of local tissue thyroxine monodeiodination to the nuclear 3,5,3'triiodothyronine in pituitary, liver and kidney of euthyroid rats. Endocrinology. 103:1196-1207.

56. Eberhardt, N. L., T. Valcana, and P. S. Timiras. 1978. Triiodothyronine nuclear receptors: an in vitro comparison of the binding of triiodothyronine to nuclei of adult rat liver, cerebral hemisphere, and anterior pituitary. Endocrinology. 102:556-561.

57. Coulombe, P., J. Ruel, R. Faure, and J. H. Dussault. 1983. Pituitary nuclear triiodothyronine receptors during development in the rat. Am. J. Physiol. 245:E81-E86.

58. von Overbeck, K., and Th. Lemarchand-Beraud. 1983. Modulation of thyroid hormone nuclear receptor levels by L-triiodothyronine $\left(\mathrm{T}_{3}\right)$ in the rat pituitary. Mol. Cell. Endocrinol. 33:281-292.

59. Samuels, H. H., F. Stanley, and L. E. Shapiro. 1977. Modulation of thyroid hormone receptor levels by 3,5,3'-triiodo-L-thyronine in $\mathrm{GH}_{1}$ cells. J. Biol. Chem. 252:6052-6060.

60. Seelig, S., H. L. Schwartz, and J. H. Oppenheimer. 1981. Limitations in the conventional analysis of the interaction of triiodothyronine with solubilized nuclear receptor sites. J. Biol. Chem. 256: 2154-2161. 